UDC 342.922

DOI https://doi.org/10.32849/2663-5313/2021.9.12

\author{
Khrystyna Solntseva, \\ Candidate of Legal Sciences, Associate Professor, Associate Professor at the Department of \\ Administrative Law and Administrative Activities, Yaroslav Mudryi National Law University, 77, \\ Pushkinska street, Kharkiv, postal code 61024, kvsolntseva@gmail.com \\ ORCID: orcid.org/0000-0001-9404-8029 \\ Scopus-Author ID: 57193097041
}

Solntseva, Khrystyna (2021). Measures to prevent corruption of officials of the National Police of Ukraine. Entrepreneurship, Economy and Law, 9, 79-87, doi: https://doi.org/10.32849/ 2663-5313/2021.9.12

\title{
MEASURES TO PREVENT CORRUPTION OF OFFICIALS OF THE NATIONAL POLICE OF UKRAINE
}

Abstract. Purpose. To define the concept of corruption, its features, anti-corruption measures used by the National Police of Ukraine; to study foreign experience in preventing corruption in the police; to outline proposals for improving existing legislation. Research methods. The paper is based on general scientific and special methods of scientific knowledge. Results. The author has defined the concept of corruption and its features. The ways of preventing corruption in the National Police of Ukraine and the practice of foreign countries in preventing corruption in the police have been analysed. Suggestions have been made to improve ways of preventing corruption in the National Police. Conclusions. The prevention of corruption is an essential component of the internal organizational activities of the National Police of Ukraine, which is aimed at ensuring such principles of the National Police as the rule of law, legality, respect for human rights and freedoms, etc. The National Police carries out a set of measures, which can be divided into institutional-regulatory and organizational, designed to prevent corruption. However, unfortunately, the level of trust in the relevant public body remains low enough. In this context, it is advisable to address foreign experience with further formation of anti-corruption policy in the National Police. At the same time, it is worth emphasizing that foreign experience should be applied given national specifics. For example, it would not be appropriate to introduce the institution of accountability of the police head following the case of the United States, as this may lead to a "vicious circle" in which the head is responsible for a subordinate and therefore is not interested in prosecuting the latter. Thus, the prevention of corruption of officials of the National Police of Ukraine is an important component of not only the anticorruption policy of the National Police but also the anti-corruption policy of the state, which should be supported both by regulatory measures and specific measures to eliminate corruption risks including precautionary measures and liability measures to be applied in case of inefficiency of the former.

Key words: National Police of Ukraine, corruption, corruption risk, illegal profit, bribe.

\section{Introduction}

Corruption is a phenomenon that has long parasitized society. Aristotle noted that officials "are sometimes prone to bribing and thus, often sacrifice state affairs for the sake of pandering. Therefore, it would be better if they were under control" (International. «Corruption perceptions index 2018», p. 192). Nowadays, corruption is a burning issue as well that is confirmed by the 2018 Corruption Perceptions Index published by Transparency International, which ranks Ukraine $120^{\text {th }} \mathrm{h}$ and gives 32 points out of 100 (About the National Police: Law of Ukraine dated 02.07.2015 No 580-VIII).

Corruption prevention is of great importance in public authorities, which deal with maintaining the rule of law, ensuring legality, compliance with a legal order, respect for human rights and freedoms because the listed affects social life. The National Police of Ukraine also belong to such authorities as the Law of Ukraine "On the National Police" (About Prevention of Corruption: Law of Ukraine dated 14.10.2014 № 1700-VII) gives the body sweeping powers to counteract administrative and legal crimes, solve them, and bring guilty persons to liability. This causes a wide range of corruption risks, and therefore, it is essential to determine preventive measures.

Many domestic and foreign scientists (Abramovska O. R., Ivantsov V. O., Lukauskaite E., Onyshchuk O. O., Romanov M. V., Titunina K. V., Shatrava S. O., et al.) whose contributions are key sources for identifying 
preventive measures in the fight against corruption in the National Police of Ukraine dealt with corruption manifestations, incl. within law-enforcement bodies.

2. Corruption manifestations in the police: concepts, elements, and particularities

Before identifying the basic principles of corruption prevention among officials of the National Police of Ukraine, it is necessary to clarify what corruption means. At present, there is no legal definition of "corrupt practices". However, the Law of Ukraine "On Prevention of Corruption”, Art. 1, defines corruption as "the use by a person referred to in Part One, Article 3 of this Law of granted official powers or powers associated with opportunities to obtain unlawful benefit or receipt of such benefit or receipt of a promise/offer of such benefit for himself/herself or others, or respectively the promise/offer or granting of an unlawful benefit to the person referred to in Part One, Article 3 of this Law or upon his/ her request to other persons or entities with a view to persuade the person to misuse his/her official powers or associated opportunities" (Bilodid I.K., 1980). Art. 3 of the Law attributes persons authorized to perform the functions of government or local self-government to potential subjects of corruption crimes. Art. 1 of the Law of Ukraine "On the National Police" establishes that the National Police is the central executive body (About Prevention of Corruption: Law of Ukraine dated 14.10.2014 № 1700-VII). As a result, one can conclude that officials of the National Police of Ukraine may be a potential subject of corruption. The Academic Explanatory Dictionary of the Ukrainian Language notes that a manifestation is a particular action or process that makes someone's state, feelings, intentions, etc., clear and noticeable. (Report on the implementation by the National Police of Ukraine during 2017 of the State Program for the implementation of the principles of state anti-corruption policy in Ukraine (Anti-Corruption Strategy) for 2015-2017 and the Anti-Corruption Program). In view of the above, it is established that corruption practices are relevant acts revealing corruption. Thus, corruption practices of officials of the National Police are acts when an official of the National Police uses his powers or related opportunities to obtain an illegal benefit or accepts it or promise/offer of such a benefit to himself/herself or others, or a promise/ offer, or the provision of an illegal benefit to an official of the National Police, or at his/her request to other natural or legal persons to persuade a person to misuse his official powers or related opportunities.
By relying on the above definition, one can distinguish the following elements of corruption practices in the National Police:

- an official of the National Police is the obligatory actor of the so-called "corruption" relations. Exclusively Art. 18 of the Criminal Code of Ukraine contains the definition of the concept "official": "officials are persons who permanently, temporarily, or by special authority perform the functions of the representatives of the government or local self-government, as well as permanently or temporarily hold positions in state authorities, local self-government bodies, enterprises, institutions, or organizations related to the performance of management or administrative-economic functions, or perform such functions under special authority, which a person is granted by an authorized body of state power, local government, central government body with special status, authorized body or official of the enterprise, institution, organization, court, or the law "(Criminal Code of Ukraine: Law of Ukraine dated 05.04.2011 № 2341-III). Consequently, one can mark that an official of the National Police of Ukraine is a person whose powers involve performing the functions of the National Police of Ukraine, that is, a police officer. According to para.1 of Art. 17 of the Law of Ukraine "On the National Police", a police officer is "a citizen of Ukraine who has taken the oath of allegiance to the Ukrainian people, serves in the police holding a particular post, and has a special police rank" (About Prevention of Corruption: Law of Ukraine dated 14.10.2014 № 1700-VII);

- they are usually manifested in the acts related to the adoption or, conversely, non-adoption of a decision, rendering of which is part of the duties of a police officer (for example, dismissal of the investigator from the pre-trial investigation by the relevant head of the National Police), or related opportunities (for example, familiarization with the files of an administrative case by the third parties who don't bear on matters);

- the decision is made or, conversely, not made due to the police officer's receipt of an illegal benefit or the receipt of a promise of its provision, etc. Adoption or non-adoption of a decision is not mandatory; it is sufficient to obtain an illegal benefit or promise of its provision, etc. to confirm corruption.

According to Annex 3 to the 2017 Report on the implementation by the National Police of Ukraine of the State Program for the Implementation of the State Anti-Corruption Policy in Ukraine (Anti-Corruption Strategy) for 2015-2017 and the NPU's Anti-Corruption Program for 2017, 32 corruption risks were 
revealed in the National Police of Ukraine; they can be divided into the following five groups:

1) related to police officers' unjustified discretionary powers (the use of official vehicle, use of information provided by the Motor (Transport) Insurance Bureau of Ukraine, etc.);

2) related to the dishonesty of a police officer (in particular, during public procurement, the investigator's dishonesty during a pre-trial investigation (when deciding to cease criminal proceedings, etc.), dishonesty during the processing of requests for information and appeals of citizens, dishonesty in the provision of administrative services (issuance of weapons permits), etc.);

3) related to the poor regulation of some procedures (for example, the lack of the agreed procedure for processing reports of corruption);

4) related to the influence of third parties (in particular, in cases of granting police officers state and government awards; the influence of third parties on employees of the Legal Department of the National Police representing the interests of the police in court);

5) other risks (delays in conducting specific background checks of candidates for particular positions; conflict of interest, etc.) (On approval of the Methodology for assessing corruption risks in the activities of public authorities: Decision of the National Agency for Prevention of Corruption dated 02.12.2016).

According to Methodology for corruption risk assessment in the activities of government authorities approved by the Decision of the National Agency on Corruption Prevention dated 02.12.2016, No. 126, corruption risk is "the likelihood of a corruption offense or a corruption-related offense, which will negatively affect the achievement of specific goals and objectives by a government body" (On approval of the Methodology for assessing corruption risks in the activities of public authorities: Decision of the National Agency for Prevention of Corruption dated 02.12.2016). Based on the above definition, it is concluded that corruption risk is a direct prerequisite for the emergence of corrupt practices. Therefore, the prevention of corruption should primarily cover activities to eliminate corruption risks.

3. On basic mechanisms for preventing corruption in the National Police of Ukraine

The Anti-Corruption Program of the National Police of Ukraine approved by the Order of the National Police as of March 20, 2019, No. 246 stipulates that "activities of the National Police of Ukraine on corruption prevention and detection include the creation and implementation of preventive anti-corruption mechanisms, elimination of potential corruption offenses, and iden- tification of corruption risks arising during the exercise of their powers" (Anti-corruption program of the National Police of Ukraine for 2019-2021). Onyshchuk O. O. defines corruption prevention as "avoidance, preliminary obstruction of corruption" (Onyshchuk O.O., 2010 , pp. 35-37). In other words, prevention should be defined exclusively as a preventive activity aimed at suppressing corruption. The Academic Glossary defines activities as "a set of actions or means of achieving, implementing something" (Report on the implementation by the National Police of Ukraine during 2017 of the State Program for the implementation of the principles of state anti-corruption policy in Ukraine (Anti-Corruption Strategy) for 2015-2017 and the Anti-Corruption Program). Therefore, measures to prevent corruption of National Police officials should be regarded as a set of preventive actions and means aimed at suppressing and averting corrupt acts committed by National Police officials.

In the author's opinion, the analysis of existing legislation allows separating two groups of measures to prevent corruption of officials of the National Police of Ukraine. Thus, the measures can be divided into general, i.e., inherent in all public authorities, including the National Police, and special, which are carried out exclusively by the National Police. In particular, according to S.O. Shatrava, the former comprises the execution of an anti-corruption examination of regulations; restrictions on gifts; outreach activity; restrictions on dual job-holding and activity overlapping; restriction on joint work of close persons; settlement of conflict of interest; auditing; establishment and administration of the Unified State Register of Persons Who Have Committed Corruption or Corruption-Related Offenses; establishment and administration of the Unified State Register of Declarations of Persons Authorized to Perform the Functions of the State or Local Self-Government, etc. (Shatrava S. O., 2018, p. 431). These methods are characterized by the fact they take place within of state power and self-government, other state bodies, enterprises, institutions, and organizations, and, as a rule, are established by interbranch regulations. In particular, they are represented by the Law of Ukraine "On Prevention of Corruption", "On Prevention and Counteraction to Legalization (Laundering) of Criminal Proceeds, Terrorist Financing, Financing of Proliferation of Weapons of Mass Destruction", "On Civil Service", etc.

As for special measures preventing corruption of officials of the National Police, they, in turn, are divided into statutory-institutional and organizational. 
The first group of special anti-corruption measures consists of measures related to the creation of an institutional system of structural units and officials whose activities are aimed at preventing corruption; approval of anti-corruption regulations.

First of all, such units should include the Corruption Prevention and Lustration Department of the National Police of Ukraine, which was established by the Order of the National Police of Ukraine No. 160 as of 23.02.2017 (Regulations on the Office for the Prevention of Corruption and Lustration of the National Police of Ukraine: Order of the National Police of Ukraine). The Department's powers cover: the interpretation of anti-corruption laws to police officers, identification of a conflict of interest, keeping records of employees of the National Police of Ukraine prosecuted for committing corruption offenses, etc. In addition to the mentioned unit, the Commission on Corruption Risk Assessment and Monitoring of the Anti-Corruption Program of the National Police of Ukraine was introduced by the Order No. 150 as of 22.02.107 (On approval of the Regulations on the Commission for Corruption Risk Assessment and Monitoring of Implementation of the Anti-Corruption Program of the National Police of Ukraine: Order of the National Police of Ukraine dated 22.07.107). The Commission's competence embraces the setting of the scope of official activities of bodies and units of the National Police vulnerable to corruption risks, identification of corruption risks, coordination of the annual anti-corruption program, etc. Some persons are entitled to handle anti-corruption issues in the National Police of Ukraine: Head of the National Police of Ukraine, his deputies, chiefs of various divisions and departments (Department of Internal Security, Department of Communications, Office for the Prevention of Corruption and Lustration of the National Police).

Activities of the above bodies and officials are based on the Anti-corruption program of the National Police of Ukraine approved by the Order of the National Police No. 246 as of 20.03.2019 (Anti-corruption program of the National Police of Ukraine for 2019-2021), which is developed to establish a complex of standards, rules, and procedures laying the groundwork for prevention, detection, and countering corruption in the National Police of Ukraine.

The second group of special anti-corruption measures includes measures related to the statutory enshrinement of relevant regulations designed to specify the powers of a police officer, improve some procedures, etc. The peculiarity of these measures is that they are derived from the former. Thus, the authorized bodies and officials identify the relevant corruption risks while exercising their powers. This, in turn, allows creating a regulatory framework to combat them. The measures are characterized by the fact that they are carried out to prevent the so-called "current manifestations of corruption" found out by the above bodies during the assessment of corruption risks.

In 2018, the National Police took a great deal of anti-corruption measures, including, the development and approval of the Order "On the introduction of the information sub-system "Official Motor Transport" into bodies and departments" No. 439 as of 27.04.2017 (the system is designed to limit too wide-ranging discretionary powers of a police officer regarding the use of official transport and strengthen control over the use of vehicles); approval of the Commission on examining documents and other physical storage media containing official information, the Order of the National Police of Ukraine as of 02.05.2018, No. 444 amended the List of records constituting official information in the system of the National Police of Ukraine to prevent potential dishonesty of police officers when using the data; it was formed commissions on transfer, discarding, inventorying property to ensure transparency of decisions on the use of the real estate, repairs, lease, etc.; one hundred and twelve FORD and FIAT vehicles equipped with GPS and video surveillance cameras, etc. were purchased and handed over to the territorial units of the National Police to control the movement of arrested and detainees during their escorting (On approval of the Methodology for assessing corruption risks in the activities of public authorities: Decision of the National Agency for Prevention of Corruption dated 02.12.2016).

4. Foreign experience in preventing corruption of police officers: the experience of Lithuania, Latvia, and the USA

Despite the measures taken by the National Police, in 2018, the American Chamber of Commerce in Ukraine presented the Results of the chamber corruption perception survey in Ukraine 2017, demonstrating that the police are among the most corrupt bodies in the country, including courts, local governments, prosecutors, etc. (American Chamber of Commerce in Ukraine. Results of chamber corruption perception survey, 2017). In this regard, it is essential to analyze the experience of foreign countries in preventing police corruption and identify priority areas for Ukraine.

The Republic of Lithuania. According to Transparency International, the peak level of police corruption in Lithuania was revealed in traffic control units (Transpar- 
ency International Lietuvos skyrius. TILS susipažįsta su Policijos departamento vykdoma corruption corruption. TILS Direktorius R. Juozapavičius discusses with the police department of vadovais apie corruption police tyrimus and corruption pr). In particular, there were frequent occurrences when a traffic offender could avoid administrative liability by passing a bribe and a police officer, in turn, deleted information about the offense from the relevant media (wiped data from a breathalyzer, a radar speed gun, etc.). This problem was solved by the implementation of the Anti-Corruption Police Program for 2012-2014, which prescribed the creation of a unified information system. The system automatically sent data from the devices recording offences to the system, and thus, some police officers could not delete data and had to bring perpetrators to liability (Elvyra Lukauskaitè, 2016, p. 37).

Moreover, just like in Ukraine, Lithuanian police experienced cases of the police's misuse of official vehicles. The deprivation of individual units of official vehicles and their registration in the unified system of police transport solved the problem. Nowadays, a police officer who needs an official car must log in to the system and fill in data on the intended usage of an official vehicle. In addition, every vehicle is equipped with a satellite monitoring system (Elvyra Lukauskaitè, 2016, p. 38).

The Republic of Latvia. In Latvia, the Corruption Prevention and Combating Bureau of the Republic of Latvia, which is an individual state body subordinated to the Cabinet of Ministers, is entrusted to fight against corruption in law enforcement agencies. The Bureau has enormous enough anti-corruption powers, including: audit of officials of all state bodies, verification of their declarations, detection of conflicts of interest, pre-trial investigation of all corruption crimes committed in state institutions, etc. (Korupcijas novēršanas un apkarošanas biroja likums dated 01.05.2002). Thus, bringing police officers to liability for all corruption offenses (both administrative and criminal) is the responsibility of an independent body, the Corruption Prevention and Combating Bureau, which guarantees an impartial investigation into the case.

Moreover, in accordance with the Rules of Monthly Work Remuneration and Special Allowances for Officials Holding Particular Ranks in the Ministry of the Interior and the Penitentiary Administration adopted by the Cabinet of Ministers, police officers are provided with an allowance for "a direct fight against serious crimes" (bribery belongs to this category of crimes). Thus, police officers can expect a bonus of up to 285 euros for the detention of bribe-takers.

Cooperation with the media was another quite effective way to prevent corruption. As a result, citizens seldom offer bribes in fear of criminal prosecution and damage to their reputation, as the media often elucidate bribery cases. (Antykorruptsyonnaia set OESR v stranakh Vostochnoi Evropi y Tsentralnoi Azyy. Predotvrashchenye korruptsyy na otraslevom urovne v stranakh Vostochnoi Evropi y Tsentralnoi Azyy na prymere sfery obrazovanyia, dobivaiushchei otrasly y polytsyy, 2017, p. 58).

The United States of America. The USA has considerable and successful experience in combating corruption, including within the police, as evidenced by the 2018 Corruption Perceptions Index published by Transparency International, which found the United States $22^{\text {nd }}$ out of 180 and provided 71 scores out of 100 possible. The US police have a wealth of experience in applying anti-corruption measures, among which are the following:

1. Some states have restrictions for relatives of a police officer to engage in some entrepreneurial activities (in particular, activities related to gambling business, trade of lottery, alcohol, gambling, casino, etc.). Moreover, a police officer who has resigned from the police is subject to some restrictions: the police officer cannot act as a representative in cases he has been involved in as a police officer; he cannot represent the interests of persons in disputes against the police during the year, etc.) (Abramovskaia O.R., 2019, p. 125).

2. Responsibility of the head. For example, in case of corruption offences, the Los Angeles Police Department draws up a report about corruption investigation, and the head of the relevant police agency is obliged to provide written explanations about the actions of his subordinate and determine the further measures to prevent similar corruption practices in the future (Abramovskaia O. R., 2019, p. 125).

3. Impartial internal control. Every police office comprises the Internal Control Department, which doesn't recruit staff but invites them in person. A person who has worked for several years in this department is transferred to other departments: it guarantees the impartiality of the employee of the internal control department and is a safeguard against the emergence of so-called "ties". The Internal Control Department can send out undercover staff to other departments. The department directly investigates crimes committed by police officers of other departments (Foreign experience in the fight against corruption: News of the Office for the Prevention of Corruption and Lustration of the National Police of Ukraine). 
4. Financial security. A US police officer has a sufficient level of financial security, which encompasses a salary, varying with a state and post, special allowances, bonuses etc. can reach 200 thousand dollars a year, health insurance, mortgage benefits, pensions, which is 50 percent of a salary, and if the experience exceeds 30 years -75 percent of a salary (Foreign experience in the fight against corruption: News of the Office for the Prevention of Corruption and Lustration of the National Police of Ukraine)

\section{Conclusions}

Prevention of corruption is an important component of the internal organizational activities of the National Police of Ukraine, which is aimed at ensuring such principles of the National Police as the rule of law, legality, respect for human rights and freedoms, etc. The National Police carries out a set of measures, which can be divided into institutional-regulatory and organizational, designed to prevent corruption. Unfortunately, the level of trust in this public body remains low enough - 30.4\% (Study of the Kharkiv Institute for Social Research on a joint project with the Kharkiv Human Rights Group with the support of the European Union «Fight against torture, ill-treatment and impunity in Ukraine»). In this regard, it is advisable to take into account foreign experience with further formation of anti-corruption policy in the National Police. At the same time, it is worth emphasizing that foreign experience should be applied given national specifics. For example, it would not be appropriate to introduce the institution of accountability of the head of the police following the case of the United States, as this may lead to a "vicious circle": the head is responsible for a subordinate, and therefore, is not interested in prosecuting the latter. At the same time, it would be expedient to make the following amendments keeping in mind a foreign experience:

1. Improving financial security of police officers, the introduction of bonuses for refusal to receive illegal benefits, and record of relevant offenses by modifying paragraph 12 of the Procedure and conditions of payment of cash security to police officers of the National Police and cadets of higher educational institutions of the Ministry of Internal Affairs with specific training conditions. Improving financial security would be one of the keys to dissuading a police officer from corrupt practices because one of the primer reasons for corruption is the need for additional earnings.

2. Amendments to the Code of Ukraine on Administrative Offenses, in particular, to sanctions of the articles of Chapter 13-A "Administrative Offenses Related to Corruption", in terms of increasing fines and the option of confiscating items or money if they were obtained through corruption - it should be applied not only to repeated offenses but also the first offense. At the same time, liability for corruption offenses is an extreme measure of influence that shall be preceded by preventive measures, which must be aimed at avoiding, averting, and making it impossible to commit acts of corruption.

3. To create an effective anti-corruption system, it would be relevant to amplify the institutional and regulatory measures designed to prevent corruption creating a mechanism of independent external control following the path taken by Lithuania. Thus, this requires supplementing para. 1 of art. 16 of the Law of Ukraine "On the National Anti-Corruption Bureau of Ukraine" by authorizing NABU to keep anti-corruption control over the National Police of Ukraine, which will be carried out in the manner approved by the Cabinet of Ministers of Ukraine.

4. Given the positive experience of Lithuania, the burning issue is to mitigate the effect of the human factor through maximum automation and informatization of control systems. For regulatory support of this measure, it would be necessary to amend art. 40 of the Law of Ukraine "On the National Police of Ukraine" by extending it with part 3 "Storage and use of information obtained through technical devices and means that have the functions of photo and filming, video recording, or means of photo and filming, video recording is carried out using an automated information collection system. In addition, to ensure the operation of this system, it is necessary to develop and adopt a relevant regulation, which is approved by the order of the National Police of Ukraine. This novelty makes it impossible for a police officer to delete evidence of an offense committed by the person who has provided an illegal benefit. Moreover, a system of preliminary analysis and prediction of relevant offenses can be an effective anti-corruption tool. The system allows identifying existing problems during career, shortcomings of the executive team, preconditions for the misuse of official powers of police officers, etc. It relies on an analysis of the major elements of police activity: the identity of the police officer, his tasks, the composition of the shift, the route, etc.

5. The cooperation of the National Police with the public and the media should be an essential aspect of preventing corruption. Thus, it is necessary to inform the public about the inadmissibility of providing illegal benefits to the police, highlighting the negative consequences of corruption, etc. 
Consequently, the prevention of corrupt practices of officials of the National Police of Ukraine is the critical part of both the anti-corruption policy of the National Police and the anti-corruption policy of the state, which should be supported by regulatory measures and specific measures to eliminate corruption risks comprising preventive measures and penalties to be applied in case of inefficiency of the former.

\section{References:}

Abramovskaia O. R. (2019). Opit protyvodeistvyia korruptsyy v polytsyy SShA. [Experience in combating corruption in the US police] Vestnyk Cheliabynskoho hosudarstvennoho unyversyteta. 2015. № 4 (359). Pravo. pp.183-186 (in Ukrainian).

American Chamber of Commerce in Ukraine. Results of chamber corruption perception survey 2017. URL: http://publications.chamber.ua/2018/Chamber_CPS 2017.pdf (in English).

Antykorruptsyonnaia set OESR v stranakh Vostochnoi Evropi y Tsentralnoi Azyy. Predotvrashchenye korruptsyy na otraslevom urovne v stranakh Vostochnoi Evropi y Tsentralnoi Azyy na prymere sferb obrazovanyia, dobivaiushchei otrasly y polytsyy. 2017. p. 84. [OECD anti-corruption network in Eastern Europe and Central Asia. Prevention of sectoral corruption in Eastern Europe and Central Asia through education, mining and policing] URL: https://www.oecd.org/ corruption/acn/OECD-ACN-Study-Corruption-Prevention-Sector-Level-2017-RUS.pdf (date of application 01.09.2021). (in Russian).

Antykoruptsiina prohrama Natsionalnoi politsii Ukrainy na 2019-2021 roky: Nakaz Natsionalnoi politsii vid 20.03.2019 № 246. [Anti-corruption program of the National Police of Ukraine for 2019-2021] URL: https://www.npu.gov.ua/about/zapobigannya-korupcziji/antukor-programu-npy.html (date of application 27.08.2021). (in Ukrainian).

Bilodid I. K. (1980). Slovnyk ukrainskoi movy: V 11 t. [Dictionary of the Ukrainian language] K. (in Ukrainian).

Doslidzhennia Kharkivskoho instytutu sotsialnykh doslidzhen za spilnym proektom z Kharkivskoiu pravozakhysnoiu hrupoiu za pidtrymky Yevropeiskoho Soiuzu «Borotba proty katuvan, pohanoho povodzhennia ta bezkarnosti v Ukraini». [Study of the Kharkiv Institute for Social Research on a joint project with the Kharkiv Human Rights Group with the support of the European Union "Fight against torture, ill-treatment and impunity in Ukraine"] URL: http://khpg.org/index. php?id=1550061985. (date of application 10.09.2021). (in Ukrainian).

Elvyra Lukauskaitė (2016). Korupcijos prevencijos policijoje problemos ir tobulinimo galimybès (Problems of Prevention of Corruption in the Police Institution and Improvement Opportunities). Magistro baigiamasis darbas. p. 72. URL: https://vb.mruni.eu/object/elaba:16098719/index. html (date of application 01.09.2021) (in Lithuanian).

International. «Corruption perceptions index 2018». URL: https://www.transparency.org/ cpi2018 (in English).

Kryminalnyi kodeks Ukrainy: Zakon Ukrainy vid 05.04.2011 № 2341-III [Criminal Code of Ukraine: Law of Ukraine]. URL: https://zakon.rada.gov.ua/laws/show/2341-14 (date of application 26.08.2021). (in Ukrainian).

Korupcijas novēršanas un apkarošanas biroja likums 01.05.2002. URL: https://likumi.lv/doc. php?id=61679 (date of application 01.09.2021) (in Latvian).

Onyshchuk O.O. (2010). Kontseptualni zasady zapobihannia ta protydii koruptsii v Ukraini [Conceptual principles of preventing and combating corruption in Ukraine] Advokat. 2010. № 9. pp. 35-37. (in Ukrainian).

Pro Natsionalnu politsiiu: Zakon Ukrainy vid 02.07.2015 № 580-VIII. [About the National Police: Law of Ukraine] URL: https://zakon.rada.gov.ua/laws/show/580-19\#Text (date of application 24.08.2021). (in Ukrainian).

Pro zapobihannia koruptsii: Zakon Ukrainy vid 14.10.2014 № 1700-VII [About Prevention of Corruption: Law of Ukraine] URL: https://zakon.rada.gov.ua/laws/show/1700-18 (date of application: 25.09.2021). (in Ukrainian).

Pro zatverdzhennia Metodolohii otsiniuvannia koruptsiinykh ryzykiv u diialnosti orhaniv vlady: Rishennia Natsionalnoho ahentstva z pytan zapobihannia koruptsii vid 02.12.2016 № 126 [On approval of the Methodology for assessing corruption risks in the activities of public authorities: Decision of the National Agency for Prevention of Corruption]. URL: https://zakon.rada.gov.ua/ laws/show/z1718-16/ed20161202\#n21 (date of application 26.08.2021). (in Ukrainian).

Polozhennia pro Upravlinnia $\mathrm{z}$ zapobihannia koruptsii ta provedennia liustratsii Natsionalnoi politsii Ukrainy: Nakaz Natsionalnoi politsii Ukrainy vid 23.02.2017 № 160. [Regulations on the Office for the Prevention of Corruption and Lustration of the National Police of Ukraine: 
Order of the National Police of Ukraine] URL: https://www.npu.gov.ua/assets/userfiles/files/protydiya-korupcii/nakaz160.pdf. (date of application 01.09.2021). (in Ukrainian).

Pro zatverdzhennia Polozhennia pro Komisiiu z otsinky koruptsiinykh ryzykiv ta monitorynhu vykonannia antykoruptsiinoi prohramy Natsionalnoi politsii Ukrainy: Nakaz Natsionalnoi politsii Ukrainy vid 22.02.107 № 150. [On approval of the Regulations on the Commission for Corruption Risk Assessment and Monitoring of the Implementation of the Anti-Corruption Program of the National Police of Ukraine: Order of the National Police of Ukraine] URL: https://www. npu.gov.ua/assets/userfiles/files/komissiya/nakaz150_.pdf. (date of application 01.09.2021). (in Ukrainian).

Shatrava S. O. (2018). Zapobihannia koruptsii v diialnosti orhaniv Natsionalnoi politsii yak neobkhidna skladova antykoruptsiinoi polityky derzhavy. [Prevention of corruption in the activities of the National Police as a necessary component of anti-corruption policy of the state]. Forum prava. № 5. pp. 427-434. (in Ukrainian).

Transparency International Lietuvos skyrius. TILS susipažịsta su Policijos departamento vykdoma korupcijos prevencija. TILS Direktorius R. Juozapavičius diskutavo su policijos departamento vadovais apie korupcijos policijoje tyrimus ir korupcijos prevenciją. URL: https://www. transparency.lt/tils-susipazista-su-policijos-departamento-vykdoma-korupcijos-prevencija-tils-direktorius-r-juozapavicius-diskutavo-su-policijos-departamento-vadovais-apie-korupcijos-policijoje-tyrimus-ir-korupcijos/ (date of application 01.09.2021). (in Ukrainian).

Zarubizhnyi dosvid u borotbi z koruptsiieiu: Novyny Upravlinnia z zapobihannia koruptsii ta provedennia liustratsii Natsionalnoi politsii Ukrainy. [Foreign experience in the fight against corruption: News of the Office for the Prevention of Corruption and Lustration of the National Police of Ukraine.] URL: https://www.npu.gov.ua/materials/novini-upzkpl/zarubizhnij-dosvid-u-borotbi-z-korupczijeyu. (date of application 03.09.2021). (in Ukrainian).

Zvit z vykonannia Natsionalnoiu politsiieiu Ukrainy uprodovzh 2017 roku Derzhavnoi prohramy shchodo realizatsii zasad derzhavnoi antykoruptsiinoi polityky v Ukraini (Antykoruptsiinoi stratehii) na 2015-2017 roky ta Antykoruptsiinoi prohramy NPU na 2017 rik [Report on the implementation by the National Police of Ukraine during 2017 of the State Program for the implementation of the principles of state anti-corruption policy in Ukraine (Anti-Corruption Strategy) for 2015-2017 and the Anti-Corruption Program of the NPU for 2017]. URL: http:// patrol.police.gov.ua/prevent/h3-antykoruptsijni-programy-npu-otsinka-koruptsijnyh-ryzykiv-u-diyalnosti-npu-h3-br/ (date of application 26.08.2021). (in Ukrainian).

\section{Христина Солнцева,}

кандидат юридичних наук, доцент, доцент кафедри адміністративного права та адміністративної діяльності, Національний юридичний університет імені Ярослава Мудрого, вулиия Пушкінська, 77, Харків, Україна, індекс 61024, kvsolntseva@gmail.com

ORCID: orcid.org/0000-0001-9404-8029

Scopus-Author ID: 57193097041

\section{ЗАХОДИ ЗАПОБІГАННЯ КОРУПЦІЙНИМ ПРОЯВАМ ІЗ БОКУ СЛУЖБОВИХ ОСІБ НАЦІОНАЛЬНОЇ ПОЛІЦІї УКРАЇНИ}

Анотація. Мета статті - визначити поняття корупційного прояву та його ознаки, заходи запобігання корупційним проявам, що використовуються Національною поліцією України, а також дослідити зарубіжний досвід із запобігання корупції в поліції та надати пропозиції щодо вдосконалення чинного законодавства в зазначеній сфері. Методи дослідження. Роботу виконано на підставі загальнонаукових і спеціальних методів наукового пізнання. Результати. Визначено поняття корупційного прояву та його ознаки. Проаналізовано способи запобігання корупційним проявам у Національній поліції України та практику зарубіжних держав із запобігання корупції в поліції. Надано пропозиції щодо вдосконалення способів запобігання корупційним проявам у Національній поліції України. Висновки. Запобігання корупційним проявам є важливим складником внутрішньоорганізаційної діяльності Національної поліції України, що спрямовується на забезпечення таких принципів діяльності поліції, як верховенство права, законність, дотримання прав і свобод людини тощо. Національна поліція України проводить досить багато заходів, спрямованих на запобігання корупційним проявам, які можна поділити на інституційно-нормативні та організаційні, однак рівень довіри до цього державного органу, на жаль, залишається на досить низькому рівні. У зв'язку із цим доцільним є врахування зарубіжного досвіду під час подальшого формування антикорупційної політики в Національній поліції України. Водночас варто наголосити 
на тому, що зарубіжний досвід повинен застосовуватися з урахуванням національних особливостей. Так, наприклад, недоцільним є впровадження інституту відповідальності керівника органу поліції за прикладом США, оскільки це може призвести до ситуації «замкнутого кола», за якої керівник буде нести відповідальність за підлеглого, а тому не буде зацікавлений у притягненні його до відповідальності. Отже, запобігання корупційним проявам із боку службових осіб Національної поліції України є важливою складовою частиною не тільки антикорупційної політики Національної поліції України, а й антикорупційної політики держави загалом, що повинна забезпечуватися як заходами нормативного регулювання, так і конкретними заходами, спрямованими на усунення корупційних ризиків. Ці заходи повинні включати в себе попереджувальні заходи та заходи відповідальності, які мають застосовуватися в разі неефективності перших.

Ключові слова: Національна поліція України, корупція, корупційний прояв, корупційний ризик, неправомірна вигода, хабар.

The article was submitted 15.09.2021

The article was revised 05.10.2021

The article was accepted 27.10.2021 